\title{
Isolation and molecular characterization of bovine herpesvirus 4 from cattle in mainland China
}

\author{
Jun $\operatorname{Lin}^{1} \cdot$ Rui-Hong Chen ${ }^{1} \cdot$ Mu-Jiao Yang ${ }^{1} \cdot$ Yuan-Mao Zhu ${ }^{1} \cdot$ Fei Xue $^{1}$ (I)
}

Received: 17 July 2020 / Accepted: 7 October 2020 / Published online: 7 January 2021

(c) Springer-Verlag GmbH Austria, part of Springer Nature 2021

\begin{abstract}
Bovine herpesvirus 4 (BoHV-4) is one of the most important of the known viral respiratory and reproductive pathogens of both young and adult cattle. However, BoHV-4 has not been isolated or detected in mainland China prior to this study. In 2019, BoHV-4 strain 512 was isolated from cattle in Heilongiiang Province, China, using MDBK cells, and characterized by PCR, nucleotide sequence analysis, and transmission electron microscopy. Two other unknown herpesvirus strains, BL6010 and $\mathrm{J} 4034$, which were isolated from cattle in 2009 in China and stored at $-70^{\circ} \mathrm{C}$, were also propagated in MDBK cells and identified as BoHV-4 by PCR. Phylogenetic analysis based on partial nucleotide sequences of the thymidine kinase (TK) gene and glycoprotein B (gB) gene for the three isolates indicated that these three Chinese strains belong to BoHV-4 genotype 1. A preliminary virus neutralization test revealed that $64 \%$ of the 70 bovine sera (45/70) collected from Inner Mongolia Autonomous Region, China, had anti-BoHV-4 antibodies and that natural BoHV-4 infection occurred in cattle in China. Here, we report for the first time the isolation and molecular characterization of BoHV-4 from cattle in mainland China.
\end{abstract}

\section{Introduction}

Bovine herpesvirus 4 (BoHV-4) is a member of the family Herpesviridae, subfamily Gammaherpesvirinae, and genus Rhadinovirus. BoHV-4 has been isolated from cattle with a variety of clinical signs, including respiratory disease [1,2], postpartum metritis [3-6], abortion [7-12], mastitis [13-15], and vulvovaginitis [16]. It has also been isolated from apparently healthy animals [17]. Recently, BoHV-4 has also been detected in dairy cows with subclinical endoenteritis $[6,18]$. BoHV-4 has no close biological or virological relationship to other known herpesviruses infecting members of the family Bovidae [19]. Cattle are the natural hosts of this virus, but African buffaloes are also susceptible to BoHV-4 infection

Handling Editor: Akbar Dastjerdi.

Yuan-Mao Zhu

zhuyuanmao@caas.cn

Fei Xue

xuefei@caas.cn

1 Division of Livestock Infectious Diseases, State Key Laboratory of Veterinary Biotechnology, Harbin Veterinary Research Institute of Chinese Academy of Agricultural Sciences, No. 678 Haping Road, Xiang Fang District, Harbin 150069, Heilongjiang Province, People's Republic of China
[20]. It has also been isolated from calf kidney cell cultures [21], bovine arterial endothelial cell cultures [22], and from various hosts, including American bison [23], sheep [24], and cats $[25,26]$. Goats, cats, guinea pigs, and rabbits can be infected experimentally [27-29].

The role of BoHV-4 in infections of the respiratory and genital tract has been studied by several research groups. The virus has been reported to be responsible for postpartum and chronic metritis, alone or in combination with other pathogens [3]. Viral genomic DNA and antigens of BoHV-4 have been detected in the lactiferous duct and sinus epithelium of mammary tissues collected from a cow with clinical mastitis [30]. BoHV-4 has also been isolated from three vaginal discharge samples from cows with post-partum metritis, some of which had BoHV-4-specific neutralizing antibodies [4]. Ex vivo explant models have shown that BoHV-4 can replicate and invade bovine genital mucosae and respiratory epithelial cells [31, 32]. Recently, a survey showed that cows with post-partum metritis shed BoHV-4 through several bodily secretions, including vaginal secretions, nasal exudates and milk, indicating that horizontal transmission may occur in BoHV-4-positive herds [6]. Like other herpesviruses, BoHV-4 has been isolated from persistently infected cattle [33]. Latency in lymphoid tissues and prolonged viremia associated with mononuclear cells has 
been demonstrated [34]. The latent virus can be reactivated by stress factors or glucocorticoid treatment [33].

The BoHV-4 genome consists of a linear dsDNA of approximately $145 \mathrm{kbp}$ that contains a unique central sequence of $110 \mathrm{kbp}$ with $41.4 \% \mathrm{G}-\mathrm{C}$ content, flanked at both ends by tandem repeats with higher G-C content, a noncoding region called polyrepetitive DNA (prDNA) [35, 36]. The central part of the genome is well conserved among BoHV-4 strains, but the prDNA varies in size depending on the number of repetitions of a 200-bp sequence [35]. All BoHV-4 strains analyzed so far exhibit, similar restriction profiles and a well-conserved central part of the genome [37]. BoHV-4 has been divided into two groups based on the restriction pattern. One is the Movar 33/63-like (Movarlike) group and the other is the DN-599-like group. Most of the Movar 33/63-like viruses were isolated in Europe, whereas most of the DN-599-like viruses were isolated in North America [38]. In 2012, analysis of BoHV-4 strains isolated from cervico-vaginal mucus of aborted cows in Argentina revealed a high genetic divergence among strains, which could be classified in three different groups: genotype 1 comprises Movar-like strains (European prototype), genotype 2 includes DN-599-like strains (American prototype), and the novel genotype 3 includes MGA1075 and 07435 strains [37].

In 2019, we used the non-cytopathic-effect (NCPE) strain 3877 of bovine viral diarrhea virus (BVDV) to inoculate two four-month old calves to establish an animal infection model of BVDV for challenge infection. Nasal swabs and buffy coat fractions were collected and used to inoculate cultured MDBK cells for virus isolation. A cytopathic effect (CPE) similar to that caused by bovine herpesvirus was observed in cultured MDBK cells inoculated with the buffy coat fractions from one calf. An attempt was made to identify the virus isolate using a pair of primers to detect glycoprotein B (gB) of BoHV-4 [39]. A 615-bp (base pair) fragment was obtained and sequenced. A BLAST search revealed that the sequence was more than $99 \%$ identical to those of the $\mathrm{gB}$ regions of most BoHV-4 strains. The isolate was designated as BoHV-4 strain 512. Two other unknown herpesvirus strains, B6010, isolated from nasal swabs of aborted cows from Heilongjiang Province, and J4034, from nasal swabs from six-month-old calves with respiratory diseases from Shandong Province, China, in 2009 that were stored at $-70^{\circ} \mathrm{C}$, were also propagated in MDBK cells and amplified by PCR and identified as BoHV-4. So far, the isolation and detection of BoHV-4 has not been reported in mainland China. The three Chinese BoHV-4 isolates were further characterized to examine their biological properties, their genomes were partially sequenced, and the resulting sequences were used for phylogenetic analysis. The intention of the present study was to genetically characterize the three wild-type BoHV-4 strains isolated from calves and a dairy cow showing different clinical signs and to provide a foundation for future epidemiological investigations and control of BoHV-4 infections in mainland China.

\section{Materials and methods}

\section{Samples, cells and virus isolation}

Anticoagulated blood samples were collected from two four-month-old calves experimentally infected with the NCPE strain 3877 of BVDV. The buffy coat fractions were separated from the blood samples using lymphocyte separation medium and resuspended in $1 \mathrm{ml}$ of minimum essential medium (MEM, GIBCO) supplemented with 3\% fetal bovine serum (Biochrom AG, Germany). MDBK cells were cultivated in MEM that was supplemented with $10 \%$ fetal bovine serum. The separated buffy coat fractions (200 $\mu \mathrm{l})$ were inoculated onto MDBK cells cultured in 24-well cell culture plates and incubated for five days at $37^{\circ} \mathrm{C}$. The cells were harvested by freezing and thawing three times, and three blind passages were carried out until a cytopathic effect (CPE) typical of BoHV-4 was observed. Another two unknown herpesvirus isolates, B6010 and J4034, were also propagated in a monolayer of MDBK cells.

\section{PCR detection of the $\mathrm{gB}$ gene of BoHV-4 and nucleotide sequence analysis}

A pair of primers, $\mathrm{gB} 1$ and $\mathrm{gB} 2$, designed based on $\mathrm{gB}$ region of BoHV-4 strain Movar 33/63 were used to amplify parts of the gB gene [39]. An approximately 615-bp product was amplified from the BoHV-4 genomic DNA using the primers gB1 (5'-CCC TTC TTT ACC ACC ACC TAC A-3') and gB2 (5'-TGC CAT AGC AGA GAA ACA ATG A-3').

Each virus isolate was inoculated onto a monolayer of MDBK cells, and the cell cultures were harvested by freezing and thawing when CPE was observed. Viral genomic DNA was extracted from $500 \mu \mathrm{l}$ of the harvested cell culture and detected by PCR as described previously [40]. The conditions for PCR amplification were $45 \mathrm{~s}$ at $95{ }^{\circ} \mathrm{C}, 50 \mathrm{~s}$ at $58{ }^{\circ} \mathrm{C}$, and $90 \mathrm{~s}$ at $72{ }^{\circ} \mathrm{C}$, with a final extension step at 72 ${ }^{\circ} \mathrm{C}$ for $10 \mathrm{~min}$.

A band of the expected size was obtained by electrophoresis in a 1.5\% agarose gel in Tris-acetate EDTA buffer and recovered from the gel using a gel extraction kit (Thermo Fisher Scientific Inc., USA). Direct DNA sequencing was performed using an ABI A3730 automated sequencer and the primers $\mathrm{gB} 1$ and $\mathrm{gB} 2$. The BLAST search program (http://www.ncbi.nlm.nih.gov/blast/Blast.cgi) was used to identify the sequences. 


\section{Electron microscopy}

MDBK cells infected with the virus isolates were harvested and negative-stain preparations for transmission electron microscopy were made as described previously [41]. The virions were observed and photographed.

\section{Virus neutralization test}

A hyperimmune serum pool against bovine herpesvirus 1 (BoHV-1) was prepared by immunizing rabbits with purified and concentrated BoHV-1. A total of 70 bovine sera were collected from cattle in the Inner Mongolia Autonomous Region, China. A volume of $100 \mu \mathrm{l}$ of serially diluted serum samples in MEM was mixed with an equal volume of a suspension containing $100 \mathrm{TCID}_{50}$ of BoHV-4 strain 512. After incubation at $37^{\circ} \mathrm{C}$ for $1 \mathrm{hr}$, the mixture was added to an MDBK cell monolayer, and the residual virus was allowed to adsorb for $1 \mathrm{~h}$. The cells were then kept in a 5\% $\mathrm{CO}_{2}$ incubator at $37^{\circ} \mathrm{C}$ and examined daily under an optical microscope for one week to observe the appearance of CPE. The neutralizing antibody titer was defined as the highest serum dilution that resulted in reduction of CPE by at least $50 \%$. Negative control serum samples were collected from mock-inoculated rabbits.

\section{Partial sequence analysis of the TK gene of BoHV-4 isolates and phylogenetic analysis}

In addition to the $\mathrm{gB}$ sequences, partial thymidine kinase (TK) gene sequences of the three Chinese isolates were also determined. A 576-bp product encompassing the TK region was amplified from the three isolates using the primers TK1 (5'-GTT GGG CGT CCT GTA TGG TAG C-3') and TK2 (5'-TGT ATG CCC AAA ACT TAT AAT ATG ACC AG-3') as described previously [9].
A 212-nucleotide region of TK and a 435-nucleotide region of $\mathrm{gB}$ for BoHV-4 were used to construct phylogenetic trees for genetic typing of the three Chinese isolates [9]. Reference sequences from previously identified BoHV-4 isolates were also included. The phylogenetic analysis was conducted using Clustal W program and Molecular Evolutionary Genetics Analysis (MEGA) version X (https://megas oftware.net/) with bootstrap values calculated from 1000 replicates. The neighbor-joining algorithm was used for construction of the trees. To confirm the genotyping results, the deduced amino acid sequences of the corresponding proteins of genotypes 1 and 2 were also aligned with the MEGA version $\mathrm{X}$.

\section{Results}

The three isolates were cultured and passaged in MDBK cells. All three isolates uniformly produced CPE characteristic of many herpesvirus isolates, with many scattered, rounded, refractory cells and hole formation in the monolayer of MDBK cells. The gB gene fragments of BoHV-4 with the expected size of $615 \mathrm{bp}$ were detected in the three Chinese isolates by PCR (data not shown). The recovered fragments were sequenced and found in a BLAST search to be more than $99 \%$ identical to the corresponding sequences of other BoHV-4 strains. Therefore, the three Chinese isolates were identified as BoHV-4. Typical virions of approximately $100-150 \mathrm{~nm}$ in diameter were observed in negativestain preparations of MDBK cells inoculated with the three isolates (Fig. 1). None of the three isolates could be neutralized by a pool of rabbit hyperimmune serum against BoHV-1, showing that there was no cross-neutralizing between BoHV-4 and BoHV-1. Forty-five of the 70 bovine sera $(64 \%)$ had neutralization antibodies against BoHV-4 in a virus neutralization test performed using strain 512, and indicating that natural BoHV-4 infections had occurred
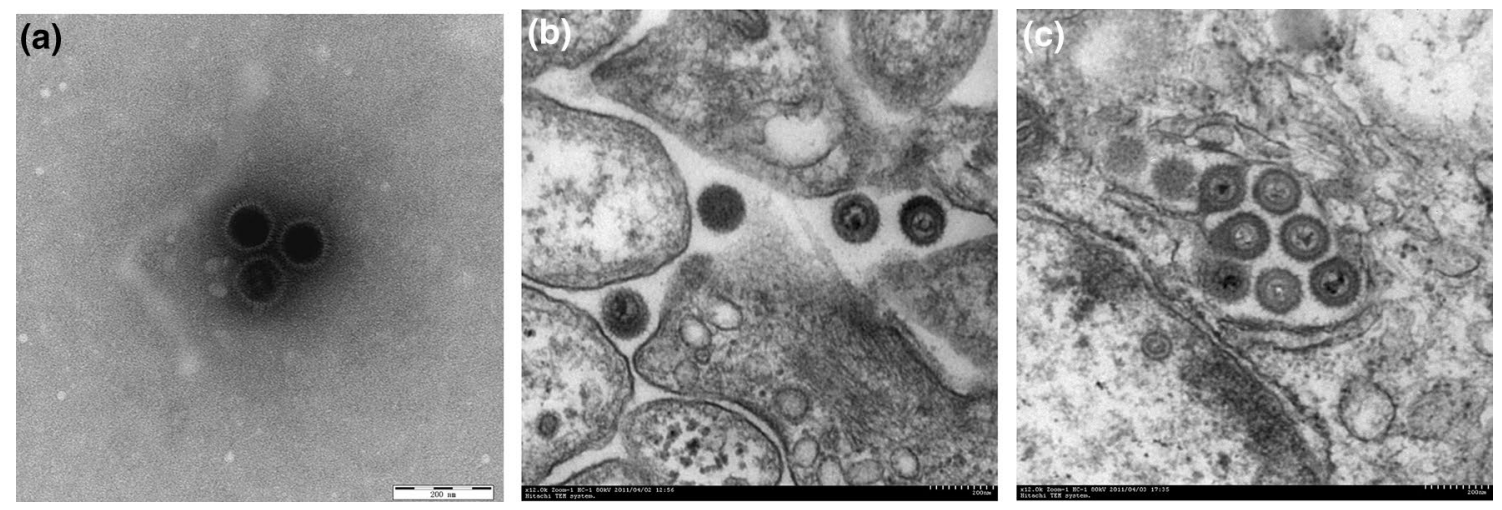

Fig. 1 Electron micrographs of the three Chinese BoHV-4 strains propagated in MDBK cell cultures exhibiting typical herpesvirus morphology. A. strain 512. B. strain J4034. C. strain B6010 
in tested cattle from Inner Mongolia Autonomous Region, China. Two BoHV-4 strains, 512 and B6010, were isolated from cattle in Heilongjiang Province, and one strain, J4034, was isolated from cattle in Shandong Province, China. However, the prevalence of this virus is still unknown, and further research is needed.

The partial TK and $\mathrm{gB}$ sequences of the three Chinese BoHV-4 isolates were deposited in the GenBank database with the accession numbers MN735172-MN735177. Using the computer program DNAStar (DNAStar Inc., Madison, WI), it was found that the level of conservation among the three Chinese isolates was very high, with 99.0 to $100 \%$ nucleotide sequence identity in the $\mathrm{gB}$ gene, and 99.8 to $100.0 \%$ identity in the TK gene. The partial TK genes amplified using the primers TK1 and TK2 were found by BLAST search to be 95.77 to $100 \%$ identical to those of other BoHV-4 strains. Alignment of the amino acid sequences encoded within the amplified $\mathrm{gB}$ fragments showed a higher level of conservation than in the nucleotide sequences between the three Chinese isolates. The predicted amino acid sequences of the partial $\mathrm{gB}$ genes of the three Chinese isolates were $100.0 \%$ identical to each other, and 84.7 to $100.0 \%$ identical to the corresponding sequences of other BoHV-4 isolates.

Phylogenetic analysis based on a 212-nucleotide region of the TK gene (Fig. 2A) showed that the three Chinese isolates clustered with BoHV-4 genotype 1 isolates. The phylogenetic analysis based on partial sequences of the $\mathrm{gB}$ region yielded similar results. The three Chinese isolates clustered together within the BoHV-4 genotype 1 lineage and formed a separate branch with a bootstrap value of $95 \%$ in the $\mathrm{gB}$ phylogenetic tree (Fig. 2B). The phylogenetic analysis based on the $\mathrm{gB}$ region was also in concordance with that based on the TK region for the BoHV-4 genotype 3 isolates. However, three Argentinean BoHV-4 isolates of genotype 2 (07 568, 08476,09759 ) did not form a separate branch, showing that
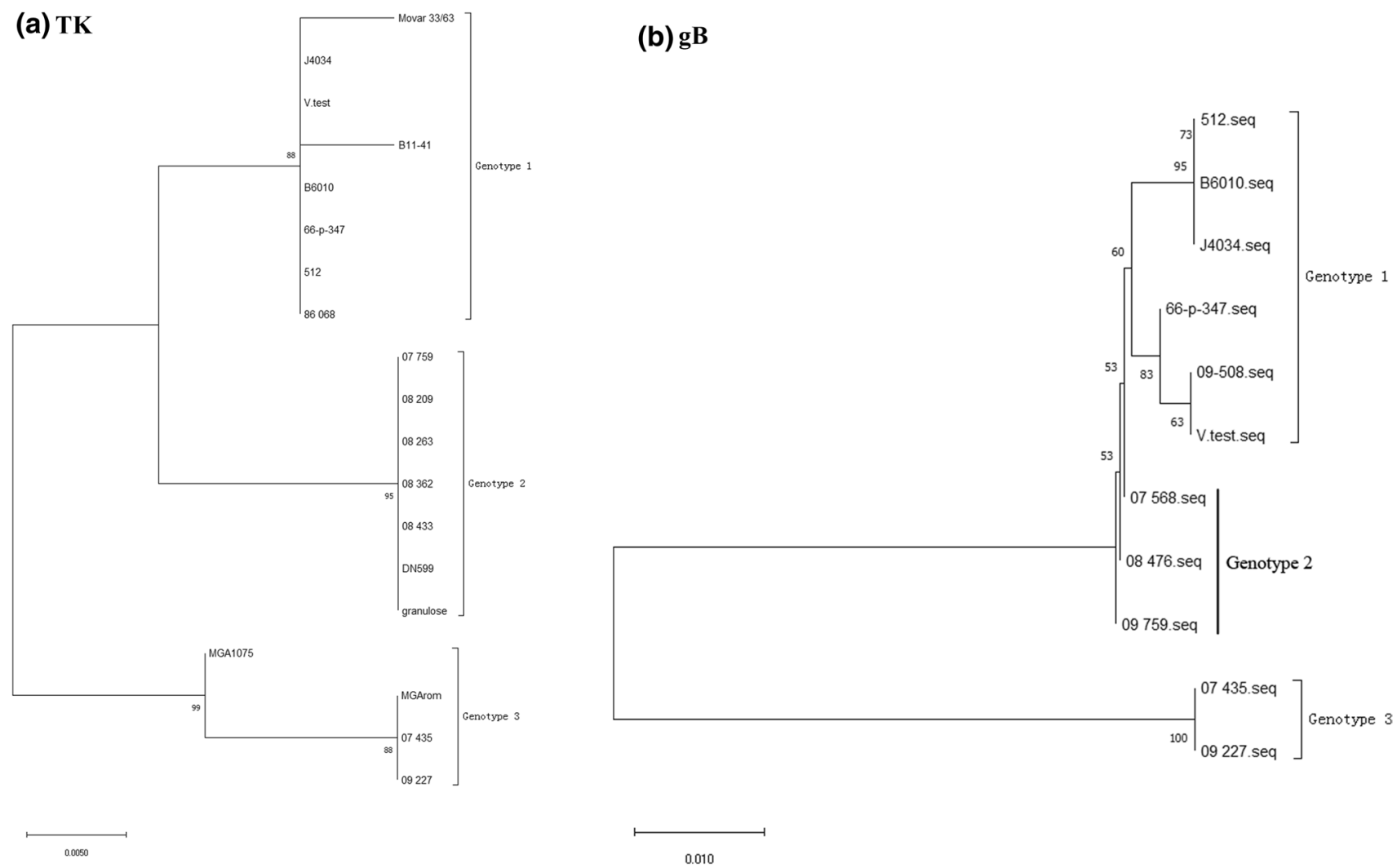

Fig. 2 Phylogeny of the three Chinese BoHV-4 isolates. The TK phylogenetic tree was constructed using TK gene nucleotide sequences of the three Chinese isolates obtained in this work and sixteen BoHV-4 reference isolates retrieved from GenBank (A TK). The gB phylogenetic tree was constructed using the $\mathrm{gB}$ gene nucleotide sequences of the three Chinese isolates detected in this work and eight BoHV-4 reference isolates retrieved from GenBank $(\mathrm{B} \mathrm{gB})$. The trees were generated using the Neighbor-Joining method and bootstrap testing. Numbers at branches indicate the percentage of 1000 bootstrap replicates that support each phylogenetic branch. The BoHV-4 reference isolates and their GenBank accession numbers are as follows: B11-41 (AB035515), Movar 33/63 (AB035516), 86068 (AB035517), V.test (JN133502), 66-p-37 (AF318573, Z15044), 07759 (JQ838048), 08 209 (JQ838049), 08263 (JQ838050), 8362 (JQ838051), 08433 (JQ838054), granulose (KP209014), DN-599 (JQ838062), 07435 (JQ838046, KP209016), 09227 (JQ838056, KP209024), MGArom (EU244697), MGA1075 (EU244700). The isolates 09508 (KU180394), 07568 (KP209017), 08476 (KP209023), and 09759 (KP209027) were only used in the $\mathrm{gB}$ tree 
the phylogenetic tree constructed using $\mathrm{gB}$ sequences was different from that constructed using TK sequences (Fig. 2A and $\mathrm{B}$ ). Therefore, the TK gene appears to be more suitable than the $\mathrm{gB}$ gene for genotyping BoHV-4 isolates. To further evaluate the use of the $\mathrm{gB}$ gene for genetic typing of BoHV-4 genotypes 1 and 2, the deduced amino acid sequences of the genotypes 1 and 2 were aligned, and a 9-amino-acid insertion was found at positions 25 to 33 of genotype 1 using MEGA version X (Fig. 3). This was observed previously with Argentinean BoHV-4 isolates [42], revealing significant differences between the $\mathrm{gB}$ gene sequences of genotypes 1 and 2. A BLAST search showed that genotypes 1 and 3 also had an 8-amino-acid insertion at positions 44 to 51 (data not shown). Therefore, the differences in $\mathrm{gB}$ amino acid sequences support the use of the $\mathrm{gB}$ gene for genetic typing of BoHV-4 genotypes 1, 2 and 3. The data obtained in this study also support use of the 212-bp fragments of the TK gene for genetic typing of BoHV-4 genotypes 1,2 and 3.

\section{Discussion}

Recently, analysis of BoHV-4 strains isolated from aborted cows in Argentina revealed a high degree of genetic divergence among strains, which could be classified into three different groups: genotypes 1,2 , and 3 [34, 42, 43]. Our preliminary results revealed that the three Chinese isolates clustered within BoHV-4 genotype 1 in both the TK and $\mathrm{gB}$ phylogenetic trees. The phylogenetic analysis using a portion of the $\mathrm{gB}$ region was in concordance with that using TK gene sequences for genotypes 1 and 3. This indicated that the $\mathrm{gB}$ region might be a candidate target for typing BoHV-4 genotypes 1 and 3, but three Argentinean BoHV-4 isolates of genotype 2 did not form a separate branch (Fig. 2B). Therefore, the phylogenetic analysis results presented here support the use of the TK gene as a suitable target for genotyping
BoHV-4 but do not fully support the use of the gB gene as a candidate target for genotype 2. A 9-amino-acid insertion was found at positions 25 to 33 of $\mathrm{gB}$ of BoHV-4 genotypes 1 and 2 (Fig. 3), and an 8-amino-acid insertion was found at positions 44 to 51 of gB of BoHV-4 genotypes 1 and 3 . In general, the data obtained from the $\mathrm{gB}$ phylogenetic tree also supported the use of a 212-bp fragment of the TK gene as a valid target for genetic typing of BoHV-4.

In order to evaluate whether the level of genetic variation presented here is typical of BoHV-4 genotypes 1, 2 and 3, more BoHV-4 genome sequences might be needed. It is notable that BoHV-4 genotypes 2 and 3 have only been detected in America, and the novel genotype 3 has only been detected in South America. Prior to this study, one BoHV-4 strain was isolated from bovine arterial endothelial cells in Taiwan, China [22]. Another strain of BoHV-4, B11-40 was isolated from the spinal cord of a cow with astasia in Japan [38]. Three BoHV-4 strains, 512, B6010, and J4034 were isolated from cattle in mainland China in this study. To date, five Asian strains have been isolated, and four of them clustered in BoHV-4 genotype 1 with the Movar-like strains (European prototype). Therefore, the results presented here suggest that the differences between genotypes 2 and 3 might be a result of geographic isolation. Sequence analysis of more BoHV-4 field isolates from different geographic regions is needed, particularly for genotypes 2 and 3 , to investigate differences between genotypes. Further immunological investigations might be required to determine the biological relevance of the three proposed BoHV-4 genotypes and their importance for future vaccine development. The identification of sequence variability is also valuable for selecting appropriate primers and excluding false-negative PCR results for BoHV-4.

BoHV-4 has been identified as one of the most important of the known viral pathogens of both young and adult cattle with respiratory or reproductive problems [2, 6, 12, 44-47].
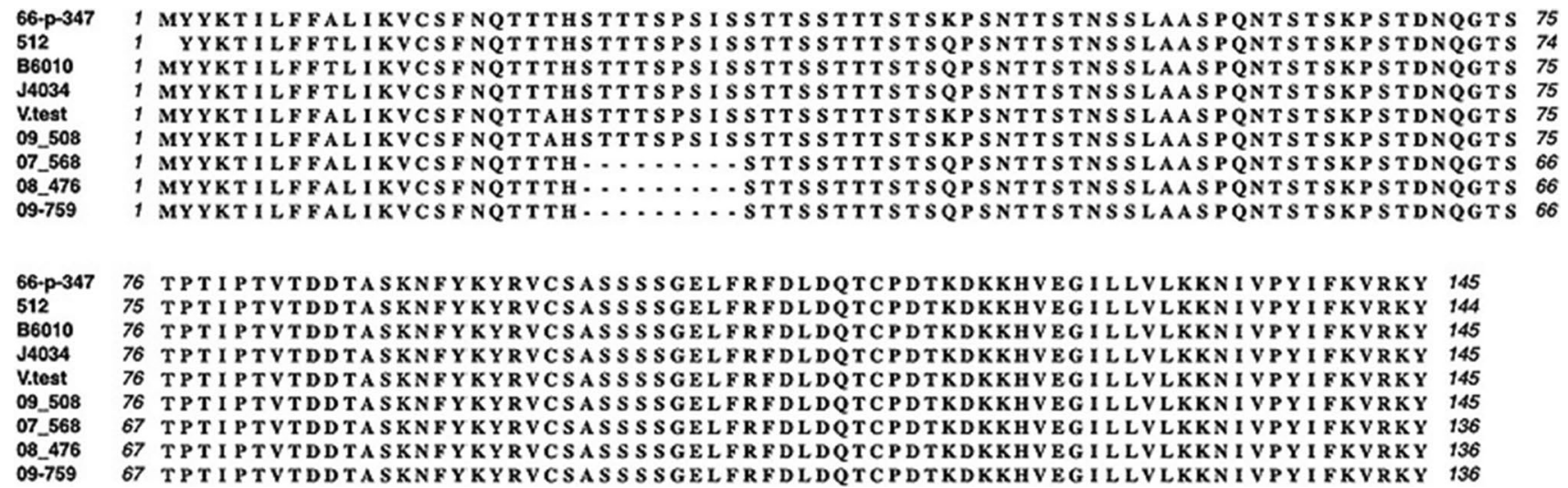

Fig. 3 Alignment of partial gB amino acid sequences of genotypes 1 (66-p-347, 512, B6010, J4034, V.test and 09_508) and 2(07_568, 08_476 and 09_759) of BoHV-4 (MEGA Version X). Missing bases in the sequence are indicated by dashes 
Recently, a strong association was found between BoHV-4 infection and lactation number, lactation stage, and postpartum metritis $[6,48]$. Respiratory and reproductive problems continue to cause substantial economic losses for the global cattle industry. BoHV-1, BVDV, bovine respiratory syncytial virus (BRSV), bovine parainfluenza virus type 3 (BPIV3), and bovine adenovirus type 3 (BAV-3) are the main recognized viral pathogens involved in the bovine respiratory disease complex (BRDC) [49, 50], but the only recognized virus involved in BRDC in China is BoHV-1, which was first isolated from cattle imported from New Zealand in 1980 [51]. BVDV infection is very common in China; however, its role in BRDC is not clear [52]. Other important viruses, such as BRSV, BPIV3 and BVA-3, have been isolated or detected in China [40, 41, 53]. So far, the only viruses known to be involved in bovine reproductive problems in China are BoHV-1 and BVDV. The isolation and detection of BoHV-4 was not reported prior to this study. This is the first report about the isolation of BoHV-4 in mainland China. Two Chinese BoHV-4 strains, B6010 and J4034, were isolated from cattle showing different clinical signs. The B6010 strain was the only virus isolated from an aborted cow. This is notable because BoHV-1 and BVDV are the main known viral pathogens involved in abortion in pregnant cows in China. This indicated that the BoHV-4 might be involved in abortion in pregnant cows. Another strain, J4034, was isolated from calves showing respiratory diseases, and it might be involved in calf respiratory disease. The BoHV-4 strain 512 was isolated from a four-month-old calf experimentally infected with an NCPE BVDV strain, but no BVDV was isolated from the calf after inoculation with BVDV. A previous infection with BoHV-4 might be a good explanation for the failure of BVDV isolation from this calf and suggests that BoHV-4 might interfere with experimental infection with BVDV. However, the role of BoHV-4 infection in respiratory or reproductive problems in cattle in China is still not known and needs further investigation.

In conclusion, partial $\mathrm{gB}$ gene sequences of the three Chinese BoHV-4 isolates from this study were $99.0 \%$ to $100.0 \%$ identical to each other, and all three appeared to belong to genotype 1 . A virus neutralization test using hyperimmune sera against BoHV-1 showed no cross-neutralization between BoHV-4 and BoHV-1. About $64 \%$ of 70 bovine sera (45/70) collected from Inner Mongolia Autonomous Region had neutralizing antibodies against BoHV-4 strain 512. This suggests that natural BoHV-4 infection in cattle might be more widespread than expected in China and that an extensive monitoring program is needed. A serological investigation will be useful to assess the host immune response to the virus. On the basis of this research, detection methods could be established for measuring antibodies against BoHV-4 and implementing epidemiological investigations of BoHV-4 in China. The new isolates could be evaluated for future BoHV-4 vaccine development. Extended research on the impact of BoHV-4 on BRDC and reproductive problems in China will be beneficial to the cattle industry.

Acknowledgements This work was supported by a partial grant from the National Key Research and Development Program of China (No. 2016YFD0500908).

\section{References}

1. Bartha A, Juhasz M, Liebermann H (1966) Isolation of a bovine herpesvirus from calves with respiratory disease and keratoconjunctivitis. A preliminary report. Acta Vet Acad Sci Hung $16: 357-358$

2. Mohanty SB, Hammond RC, Lillie MG (1971) A new bovine herpesvirus and its effect on experimentally infected calves. Brief report. Arch Gesamte Virusforsch 33:394-395. https://doi. org/10.1007/bf01254696

3. Monge A, Elvira L, Gonzalez JV et al (2006) Bovine herpesvirus 4-associated postpartum metritis in a Spanish dairy herd. Res Vet Sci 80:120-125. https://doi.org/10.1016/j.rvsc.2005.04.001

4. Nikolin VM, Donofrio G, Milosevic B et al (2007) First Serbian isolates of bovine herpesvirus 4 (BoHV-4) from a herd with a history of postpartum metritis. New Microbiol 30:53-57

5. Banks M, Ibata G, Murphy AM et al (2008) Bovine lymphotropic herpesvirus and non-responsive post-partum metritis in dairy herds in the UK. Vet J 176:248-250. https://doi.org/10.1016/j. tvj1.2007.02.005

6. Díaz JM, Prieto A, López-Lorenzo G et al (2019) Monitoring of the shedding and serological dynamics of Bovine gammaherpesvirus type 4 in a dairy cattle herd. Vet Microbiol 239:108495. https ://doi.org/10.1016/j.vetmic.2019.108495

7. Czaplicki G, Thiry E (1998) An association exists between bovine herpesvirus- 4 seropositivity and abortion in cows. Prev Vet Med 33:235-240. https://doi.org/10.1016/s0167-5877(97)00036-6

8. Deim Z, Szeredi L, Egyed L (2007) Detection of bovine herpesvirus 4 DNA in aborted bovine fetuses. Can J Vet Res 71:226-229

9. Gonzalez Altamiranda E, Manrique JM, Perez SE et al (2015) Molecular characterization of the first bovine herpesvirus 4 (BoHV-4) strains isolated from in vitro bovine embryos production in Argentina. PLoS ONE 10:e0132212. https://doi. org/10.1371/journal.pone.0132212

10. Delooz L, Czaplicki G, Houtain JY et al (2017) Laboratory findings suggesting an association between BoHV-4 and Bovine abortions in Southern Belgium. Transbound Emerg Dis 64:1100-1109. https://doi.org/10.1111/tbed.12469

11. Florencia R, Julieta M, Sandra P et al (2020) Characterization of the first bovine gammaherpesvirus 4 strain isolated from an aborted bovine fetus in Argentina. Arch Virol 165:719-723. https ://doi.org/10.1007/s00705-019-04507-3

12. Dağalp SB, Babaoglu AR, Doğan F et al (2020) An assessment of bovine herpes virus 4 as a causative agent in abortions and neonatal death. Onderstepoort J Vet Res 87:e1-e5. https://doi. org/10.4102/ojvr.v87i1.1761

13. Wellenberg GJ, Bruschke CJM, Wisselink HJ et al (2002) Simultaneous intramammary and intranasal inoculation of lactating cows with bovine herpesvirus 4 induce subclinical mastitis. Vet Microbiol 86:115-129. https://doi.org/10.1016/s0378-1135(01)00496-5

14. Kalman D, Janosi S, Egyed L (2004) Role of bovine herpesvirus 4 in bacterial bovine mastitis. Microb Pathog 37:125-129. https ://doi.org/10.1016/j.micpath.2004.06.011

15. Izumi Y, Tsuduku S, Murakami K et al (2006) Characterization of Bovine herpesvirus type 4 isolated from cattle with mastitis 
and subclinical infection by the virus among cattle. J Vet Med Sci 68:189-193. https://doi.org/10.1292/jvms.68.189

16. Castrucci G, Frigeri F, Cilli V et al (1986) A study of a herpesvirus isolated from dairy cattle with a history of reproductive disorders. Comp Immunol Microbiol Infect Dis 9:13-21. https ://doi.org/10.1016/0147-9571(86)90070-6

17. Goyal SM, Naeem K (1992) Bovid herpesvirus-4: a review. Vet Bull 62:181-201

18. Yang B, Pascottini OB, Xie J et al (2019) Presence of gammaherpesvirus BoHV-4 in endometrial cytology samples is not associated with subclinical endometritis diagnosed at artificial insemination in dairy cows. Vet Microbiol 229:130-137. https ://doi.org/10.1016/j.vetmic.2018.12.025

19. Fabian K, Makrai L, Sachse K et al (2008) An investigation of the aetiological role of bovine herpesvirus 4 in bovine endometritis. Vet J 177:289-292. https://doi.org/10.1016/j. tvj1.2007.04.010

20. Dewals B, Thirion M, Markine-Goriaynoff N et al (2006) Evolution of Bovine herpesvirus 4: recombination and transmission between African buffalo and cattle. J Gen Virol 87:1509-1519. https://doi.org/10.1099/vir.0.81757-0

21. Luther PD, Bradley PG, Haig DA (1971) The isolation and characterization of a herpesvirus from calf kidney cell cultures. Res Vet Sci 12:496-498

22. Lin TM, Shi GY, Jiang SJ et al (1999) Persistent infection of bovine herpesvirus type 4 in bovine endothelial cell cultures. Vet Microbiol 70:41-53. https://doi.org/10.1016/s0378 $-1135(99) 00132-7$

23. Todd WJ, Storz J (1983) Morphogenesis of a cytomegalovirus from an American bison affected with malignant catarrhal fever. J Gen Virol 64:1025-1030. https://doi. org/10.1099/0022-1317-64-5-1025

24. van Opdenbosch E, Wellemans G, Oudewater J (1986) Casual isolation of a bovine herpesvirus 4 from the lung of a sheep. Vlaams Diergeneeskd Tijdschr 55:432-433

25. Kruger JM, Osborne CA, Whetstone CA et al (1989) Genetic and serologic analysis of feline cell-associated herpesvirus-induced infection of the urinary tract in conventionally reared cats. Am J Vet Res 50:2023-2027

26. Kruger JM, Venta PJ, Swenson CL et al (2000) Prevalence of bovine herpesvirus-4 infection in cats in Central Michigan. J Vet Intern Med 14:593-597. https://doi.org/10.1892/08916640(2000)014\%3c0593:pobhii\%3e2.3.co;2

27. Osorio FA, Reed DE, Rock DL (1982) Experimental infection of rabbits with bovine herpesvirus-4: acute and persistent infection. Vet Microbiol 7:503-513. https://doi.org/10.1016/03781135(82)90045-1

28. Moreno-Lopez J, Goltz M, Rehbinder C et al (1989) A bovine herpesvirus (BHV-4) as passenger virus in ethmoidal tumours in Indian cattle. Zentralbl Veterinarmed B 36:481-486. https://doi. org/10.1111/j.1439-0450.1989.tb00633.x

29. Egyed L, Kluge JP, Bartha A (1997) Histological studies of bovine herpesvirus type 4 infection in non-ruminant species. Vet Microbiol 57:283-289. https://doi.org/10.1016/s0378-1135(97)00105-3

30. Miyano H, Haritani M, Sentsui H et al (2004) Mammary lesions associated with bovine herpesvirus type 4 ina cow with clinical mastitis. J Vet Med Sci 66:457-460. https://doi.org/10.1292/ jvms.66.457

31. Yang B, Li Y, Bogado Pascottini O et al (2017) Primary replication and invasion of the bovine gammaherpesvirus BoHV-4 in the genital mucosae. Vet Res 48:83. https://doi.org/10.1186/s1356 7-017-0489-3

32. Yang B, Xie J, Van Cleemput J et al (2019) Gammaherpesvirus BoHV-4 infects bovine respiratory epithelial cells mainly at the basolateral side. Vet Res 50:11. https://doi.org/10.1186/s1356 7-019-0629-z
33. Dubuisson J, Thiry E, Bublot M et al (1989) Experimental infection of bulls with a genital isolate of bovine herpesvirus- 4 and reactivation of latent virus with dexamethasone. Vet Microbiol 21:97-114. https://doi.org/10.1016/0378-1135(89)90022-9

34. Osorio FA, Reed DE (1983) Experimental inoculation of cattle with bovine herpesvirus-4: evidence for a lymphoid-associated persistent infection. Am J Vet Res 44:975-980

35. Ehlers B, Buhk HJ, Ludwig H (1985) Analysis of bovine cytomegalovirus genome structure: cloning and mapping of the monomeric polyrepetitive DNA unit, and comparison of European and American strains. J Gen Virol 66(Pt 1):55-68. https://doi. org/10.1099/0022-1317-66-1-55

36. Thiry E, Bublot M, Dubuisson J et al (1992) Molecular biology of bovine herpesvirus type 4. Vet Microbiol 33:79-92. https://doi. org/10.1016/0378-1135(92)90037-t

37. Verna AE, Manrique JM, Perez SE et al (2012) Genomic analysis of bovine herpesvirus type 4 (BoHV-4) from Argentina: high genetic variability and novel phylogenetic groups. Vet Microbiol 160:1-8. https://doi.org/10.1016/j.vetmic.2012.04.039

38. Yamamoto Y, Murakami K, Inoshima Y et al (2000) Characterization of a bovine herpesvirus type 4 isolated from the spinal cord of a cow with astasia. Arch Virol 145:2363-2370. https:// doi.org/10.1007/s007050070026

39. Wellenberg GJ, Verstraten ER, Belak S et al (2001) Detection of bovine herpesvirus 4 glycoprotein $\mathrm{B}$ and thymidine kinase DNA by PCR assays in bovine milk. J Virol Methods 97:101-112. https ://doi.org/10.1016/s0166-0934(01)00341-x

40. Zhu Y-M, Yu Z, Cai $\mathrm{H}$ et al (2011) Isolation, identification, and complete genome sequence of a bovine adenovirus type 3 from cattle in China. Virol J 8:557. https://doi. org/10.1186/1743-422X-8-557

41. Zhu Y-M, Shi H-F, Gao Y-R et al (2011) Isolation and genetic characterization of bovine parainfluenza virus type 3 from cattle in China. Vet Microbiol 149:446-451. https://doi.org/10.1016/j. vetmic.2010.11.011

42. Verna AE, Perez SE, Manrique JM et al (2016) Comparative study on the in vitro replication and genomic variability of Argentinean field isolates of bovine herpesvirus type 4 (BoHV-4). Virus Genes 52:372-378. https://doi.org/10.1007/s11262-016-1312-3

43. Pérez S, Manrique J, Morán P et al (2020) Genetic characterization of bovine herpesvirus 4 (BoHV-4) isolates from Argentine cattle suggests a complex evolutionary scenario. Mol Biol Rep 47:4905-4909. https://doi.org/10.1007/s11033-020-05449-9

44. Naeem K, Caywood DD, Goyal SM et al (1991) Variation in the pathogenic potential and molecular characteristics of bovid herpesvirus-4 isolates. Vet Microbiol 27:1-18. https://doi. org/10.1016/0378-1135(91)90058-n

45. Gur S, Dogan N (2010) The possible role of bovine herpesvirus type-4 infection in cow infertility. Anim Sci J 81:304-308. https ://doi.org/10.1111/j.1740-0929.2010.00743.x

46. Klamminger S, Prunner I, Giuliodori MJ, Drillich M (2017) Uterine infection with bovine herpesvirus type 4 in dairy cows. Reprod Domest Anim 52:115-121. https://doi.org/10.1111/rda.12865

47. Murray GM, More SJ, Clegg TA et al (2018) Risk factors associated with exposure to bovine respiratory disease pathogens during the peri-weaning period in dairy bull calves. BMC Vet Res 14:53. https://doi.org/10.1186/s12917-018-1372-9

48. Areda D, Chigerwe M, Crossley B (2018) Bovine herpes virus type-4 infection among postpartum dairy cows in California: risk factors and phylogenetic analysis. Epidemiol Infect 146:904-912. https://doi.org/10.1017/S0950268818000791

49. Tuncer P, Yesilbag K (2015) Serological detection of infection dynamics for respiratory viruses among dairy calves. Vet Microbiol 180:180-185. https://doi.org/10.1016/j.vetmic.2015.08.025

50. Hay KE, Morton JM, Clements ACA et al (2016) Associations between feedlot management practices and bovine respiratory 
disease in Australian feedlot cattle. Prev Vet Med 128:23-32. https://doi.org/10.1016/j.prevetmed.2016.03.017

51. Zhou T, Ye Z, Li S et al (1981) The isolation of infectious bovine rhinotracheitis virus from the cows imported from the New Zealand. Chin Vet Sci. https://doi.org/10.16656/j.i ssn.1673-4696.1981.01.002

52. Xue F, Zhu Y-M, Li J et al (2010) Genotyping of bovine viral diarrhea viruses from cattle in China between 2005 and 2008. Vet Microbiol 143:379-383. https://doi.org/10.1016/j.vetmi c.2009.11.010
53. Shi H, Zhu Y, Gao Y et al (2010) Detection of bovine respiratory syncytial virus by a reverse transcriptase-nested-polymerase chain reaction in bovine clinical samples. Chin J Prev Vet Med $32: 238-240$

Publisher's Note Springer Nature remains neutral with regard to jurisdictional claims in published maps and institutional affiliations. 